FILOZOFIA

Roč. 75,2020 , č. 6

DOI: https://doi.org/10.31577/filozofia.2020.75.6.3

\title{
REPUBLICAN FREEDOM AND SUBJECTIVE LEGITIMACY OF POWER
}

\author{
JUAN JOSÉ GÓMEZ GUTIÉRREZ, Faculty of Philosophy, University of Seville, Seville, Spain
}

GÓMEZ GUTIÉRREZ, J. J.: Republican Freedom and Subjective Legitimacy of Power

FILOZOFIA, 75, 2020, No 6, pp. $460-473$

\begin{abstract}
This article examines the concept of republican political freedom in connection with three aspects of the relationship between subject and State: the subject as distinct from, or opposed to, the State; the subject as established by its constitutional definition; and the subject as historical praxis of identification and deidentification with its legal, recognised form. For this, firstly, I discuss the republican concept of freedom. This is followed by a reflection on the relationship between the individual and the Modern State in terms of an analysis of the subjective legitimacy of power based on consent. Finally, I set out to examine republican political freedom from a historicist perspective, venturing some reflections on the relationship between the republican State as promoter of freedom and historical liberating practices.
\end{abstract}

Keywords: Republicanism - Freedom - Legitimacy - Subjectivity

\section{Introduction. A Gramscian reading of republicanism}

The republican subject - and republican subjective freedom - is an artificial construct resulting from collective rational agreement. From this, a distinct characterisation of State as legitimate power may follow. Republicans regard State coercion as legitimate when it preserves subjective freedom from arbitrariness. Then, if "State" means nonarbitrary power, the legitimacy of its authority depends of its perceived rationality. In other words, legitimization means rational conviction of the necessity of State interference to preserve freedom (grating the State, so to speak, a power of attorney to act in favour of the subject). Conversely, tyranny equals to delegitimization, meaning irrational - unagreed - exercise of power that threatens freedom.

Furthermore, the constitutional definition of the subject is not merely the result of an aggregation of individual reasoning. The State constructs its legitimacy by actively shaping the subjects' thought. Hence the importance of education and religion in republican political theory. They produce virtuous citizens that live their identification to public rationality as a rational necessity. 
Then, how rational evidence works as the basis of republican legitimacy? To, at least, identify some topics related to this question, I shall take as starting point Antonio Gramsci's tenet that rationality is linked to the diverse, historically contemporaneous discursive settings of interacting social groups, when they function as motivational basis of praxis. Recognition is the core of hegemonic authority, which must be elevated to truth in the others. To be "hegemonic" means a historic practice of rational definition of the body politic aimed at achieving the subalterns' consensus on the reasonability of political rule. From this perspective, in the following sections, firstly I attempt to define republican freedom. Then, it follows an analysis of the constitutional dimension of the republican free subject. I also examine how legitimacy is related to practices of identification or de-identification in face of the subject's constitutional form. In the final parts, I return to Gramsci's explanations of the dialectics of hegemonic struggles in terms of liberating processes.

It is well known that Gramsci $(1975,249)$ regarded Marx as "the founder of philosophy of praxis". Though Machiavelli, too, "expressed an original conception of the world" (Gramsci 1975, 471) which might be called "philosophy of praxis" (Gramsci 1975, 657). It seems more obvious that "the philosophy of praxis is a development of Hegelianism" (Gramsci 1975, 1487). In this way, amid vacillations, Gramsci seeks to establish a link between Machiavelli, Hegel, and Marx as members of a tradition of political thought called "Philosophy of Praxis". In this paper, I will attempt to put all these references into play for a characterization of republican freedom. In particular, Gramsci seems to take as a formal model of hegemony Hegel's Dialectic of master and servant as antagonistic wills that must raise the self-certainty of being for themselves to the truth in the other and in itself (Cf. Hegel 2018, 109). Furthermore, Hegel would be the creator of a philosophy interwoven with a "intense period of struggle", which "cannot be understood without the French Revolution and Napoleon" (Gramsci 1975, 1326). The Dialectic of master and servant postulates a common reason equally shared by the ruler and the ruled, but not equally exercised in history, the arena where the reversibility of these roles could take place. But Gramsci is aware that equalising the servant with the master can also mean voiding his possibility of liberation, a cunning of reason aimed at the servant's renunciation to express his own existence.

Italian Republican thought is also crucial for Gramsci's vision of the modern State as constituted by coercion and consensus including, for example, reflections such as that of Francesco Guicciardini, quoted in the Notebooks, that there are two things absolutely necessary for the life of a State: arms and religion (Gramsci 1975, 762 - 763). For his part, Machiavelli acted as a precursor of philosophy of praxis primarily through the way in which he presented the dialectic between subject and 
State, upon which the constitution of republican freedom and the hybrid character of subjective identity depends. The Prince does not only hold dominium. He also establishes the citizen through his legislative activity, and is a Prince only as long as he is recognised as such. ${ }^{1}$ In particular, the Discourses on Livy underline the necessity of religion "to preserve a civilization and constitute it [...], facilitating any enterprise that the Senat or the Roman leaders decided to undertake" (Machiavelli 1938, 136 137). But Machiavelli appreciates Ancient religion only in so far it serves "to command armies, to encourage the plebs, to keep men good, to make kings feel ashamed" (Machiavelli 1938, 138 - 139), concluding that it "was the main reason for the city's happiness, because it produced a good order" (Machiavelli 1938, 139 - 140).

Gramsci $(1975,1308)$ understands religion in similarly civil terms, according to "a conception of the world with a corresponding ethics" that plays a cohesive social role, being crucial to legitimising the State in the eyes of its subjects from the perspective of the universal, upon which lies the durability of the political system. The Catholic Church, in particular, had worked since the Counter-Reformation as the nucleus of this politicised secularisation of religion: "Catholicism has become 'Jesuitism'. Modernism has not created 'religious orders', but a political party" (1975, 1384). In other words, "what is most important here is that [...Jesuitism and integralism] pose in religious form problems that are often purely worldly, problems of 'rule" (Gramsci 1975, 1718). The Jacobins, "who certainly were a 'categorical incarnation' of Machiavelli's Prince" (Gramsci 1975, 952), would also seek to establish the Cult of the Supreme Being as part of their effort to forge an identity between State and civil society, constituting the "first roots of the modern secular State [...] which seeks and finds in itself, in its complex life, all the elements of its historical personality" (Gramsci 1975, 763).

Having said that, Gramsci seems to go beyond Machiavelli; since, even in the moments of most intense criticism, for example when defending the superiority of old religion, Machiavelli still attributes to Christianity a political utility. The latter still conceives of religion as a constitutive element of the State, inasmuch as it guarantees the connection between the citizens and their convictions about the utterly just nature of the political system in which they live. Gramsci, however, nuances the republican idea of civil religion as merely involving a "political passion", to use the expression bequeathed by Benedetto Croce $(1924,341)$ and later employed by Maurizio Viroli (2004). His historicism accentuates the succession of hegemonies (that is, political history itself), which depended precisely on the struggle arising from the loss of legi-

\footnotetext{
${ }^{1}$ See, for instance, Machiavelli's Sopra la Prima deca di Tito Livio LV (1938, 228): “Those republics that have preserved an uncorrupted political life does not allow the citizens not to live according to the gentry's way of life."
} 
timacy, or the demystification of the State as a result of the contingent condition of universalisation as historical practice. This implies a perspective "antithetical" to Catholic philosophy (Gramsci 1975, 1384).

\section{Republican freedom as non-domination. A Critique of Liberalism}

Michael Sandel $(2005,253)$ defines liberal politics as the search for "principles of justice that specify our rights [and] do not depend for their justification of any particular conception of the good life". The good is interpreted here in terms of recognising a fundamental purpose of society and the State: to promote the development of a common human nature. The liberal perspective problematises this idea of a human nature shared by every individual, and instead stresses public neutrality in the face of different and occasionally contradictory empirical ideas of the good, recognising the same rights for all of them in view of their de facto existence. More than goodness, the liberal State gives itself the objective of rationally accommodating these different ideas of the good life with the aim of fomenting all of them. It concerns a type of State that Sandel $(2005,158)$ calls "correct" inasmuch as it "provides the framework that regulates the play of competing values and ends". On the other hand, given the variety of potential personal objectives, the recognition of the right of the subjects regardless of these objectives presumes a self-determined subject distinct from the ends which he pursues. Basing himself on Kant and Rawls, Sandel describes a subject without content related to his choices, ambitions, desires, or conceptions of life. Autonomous with respect to the dictates of nature or social roles, the self's actions are legitimised simply by them taking place. In the correct State, the legal-political sphere dignifies the self as a "self-originating source of valid claims" regardless of what these empirical claims may be (Rawls quoted in Sandel 2005, 154).

However, the real multiplicity of individual claims leads to their potential incompatibility within a context of interaction. A state of probable conflict wherein each particular will exercises its freedom up to the limits of its power without consideration of other individuals. Hence the coercive function of the State, which artificially limits the natural liberty of pre-social subjects so as to safeguard them from the intentions of others. The liberal State as artifice and violence contradicts the subject's natural right to self-determination at the same time as it preserves that right, and never resolves the opposition between its constitution and the defence of freedom. Moreover, the fact that subjects relinquish their right to freedom means that they exercise such freedom only where the State allows.

As a matter of fact, Philip Pettit (2002, 16 and ff.) defines republican freedom from the starting point of these paradoxes. Specifically, contesting Isaiah Berlin's distinction between positive and negative freedom. That is, between freedom as self- 
government or self-fulfilment of the self, and freedom as a lack of public restrictions on obtaining that self-fulfilment. Positive freedom is the freedom exercised by the individual as such; their capacity for practical self-determination or power. Negative freedom refers to the zone of non-intervention from the State available for the exercise of subjective self-determined acts, guaranteed by a neutral legal framework in the face of potentially limiting external claims. Given this, Pettit criticises Berlin's distinction in view of its difficulty in laying the foundations of such political-legal framework, extending the function of the State beyond mere restrictive practice. Furthermore, he adds, domination may be compatible with negative liberty, for example in the case of a benevolent master who arbitrarily provides the slave with spaces of discretion.

Pettit, however, ponders the possibility of a type of public interference which is not restrictive, but promotive of freedom, dedicated to preserving each individual from the despotism of others, not diminishing their liberty. Despotism is understood as an illegitimate extension of the self to spheres where it invades the self-determined praxis of others and subdues them. The republican alternative - freedom as non-domination - proposes that the objective of the State consists in optimising freedom in the face of the perspective of the State of nature. It refers to a non-arbitrary coercive component, a type of rational coercion based on consent, consensus, and compromise, that has as its objective the quantitative increase of general freedom even at the expense of curtailing individual wills, or of these being self-restricted, as a result of a rationalisation to examine how the public sphere can promote freedom. For this, the republican State depends, in the first place, on a praxis of intersubjective deliberation; on the dialogue of mutually recognised wills which interact with each other and agree upon a constitution. Concretely, "interference occurs without any loss of liberty when the interference is not arbitrary and does not represent a form of domination: when it is controlled by the interests and opinions of those affected, being required to serve those interests in a way that conforms with those opinions" (Pettit 2002, 56).

As much as non-domination as the regulatory ideal of social relations differs from the absence of interference, it also differs from the mere recognition of the self-determined self. In the face of the minimal State, the minimal restrictive intervention of the subject and public participation based on its sovereignty, Pettit conceives of Law as nonarbitrary interference and the Rule of Law as its exercise. A connection certainly exists between the breadth of the space in which the individuals does not tolerate interference and the extension of their self-determination as a projection of their power. Having said that, the idea of freedom presented by Pettit is centred on the negative aspect of liberty as non-interference, distinguishing in this case between arbitrary and rational interference. Pettit would not consider the positive public participation of the subject as a constitutive element of republican liberty, except in the case of preventing the inclination 
to despotism on the part of those managing the State. Freedom is exercised in the first place in private space and only secondarily in public. In other words, the citizen's political participation has as its aim the limiting and monitoring of any deviation in the function of the State as a guarantor of individual liberties: "Democratic participation may be essential to the republic, but that is because it is necessary for promoting the enjoyment of freedom as non-domination, $[\ldots]$ not because freedom, as a positive conception would suggest, is nothing more or less than the right of democratic participation" (Pettit 2002, 8). In Pettit's republicanism, participatory democracy is not desirable in itself, and citizens' active control is reduced to preventing threats to freedom. From this it comes to pass that the authority of the State as rational is recognised only in a passive and formal manner. This in contrast with other republican authors, such as Jürgen Habermas, for whom participation is essential as an interlocution in order to generate a rational communicative praxis: "from the republican perspective [...] the state's 'raison d'être' does not lie primarily in the protection of equal private rights, but in the guarantee of an inclusive opinion-and will-formation in which free and equal citizens reach an understanding on which goals and which norms lie in the equal interest of all" (Habermas 1994, 8).

\section{Constitution and constituted freedom}

Let's return now to Sandel's arguments about the political subject of the correct State. Given the evidence for the multiplicity of the subjects' ends and desires, these lack a specific public definition that can express a volitional content beyond the subjects' recognition as legitimate self-originating sources of claims, which in turn establishes them politically as legitimate interlocutors. But the subject who precedes the political constitution is nothing more than a postulate empty of empirical content. It is as indefinable as it is necessary for explaining the subjective de facto praxis, in such a way that any definition of the subject can only take place after such praxis occurs in history. And this definition is not a mere reflection of the subjects' empirical, contemporary present reality. It exercises over them a power legitimated by assent and rational consensus, while this subject who precedes the legal subject remains active in the way in which social recognition is historically - practically - generated.

Machiavelli, in particular, distinguishes between the State's incomplete art of founding, maintaining, and extending a dominium (the Prince's ability to interfere with the lives of the citizens) and the general art of politics, which refers instead to the objectives of the exercise of dominium: founding a State in accordance with republican normativity. The State does not truly require this normativity; but the possible non-despotic civic State is defined precisely by its internal normativity and obtains its own legitimacy by respecting the rights of the subjects and recognising these as legitimate. The legal 
duty of submitting to the sovereign is unconditional but limited, so that, for Machiavelli, it is lawful and necessary that the citizens acquire virtue and defend their freedoms by fighting the corruption of the rulers and opposing despotic laws. ${ }^{2}$

A good education, which originates in good laws, contributes to this virtue. Thus laws, education, and freedom relate to each other through the term virtue, giving rise to the sphere of the State in a broad sense. It supposes that citizens are recognised in their legal status and behave in accordance with the law and implies, in equal measures, guarantees of respect and effective identity between individuals and their constitution. In sum, it means that from the citizens' perspective, their legal status appears to be a necessity. According to Machiavelli, through the example of civility, just as in the ancient States, where each person is from the perspective of the unconditional: "the ancient religion did not beatify men if they were not full of worldly glory, as were captains of armies and princes of republics". Although the separation between religion and State espoused by Christianity had as its result "rendered the world weak and given it in prey to criminal men" (Machiavelli 1996, 131). Civil discord and decadence appear before the bankruptcy of public morality. As Juan Manuel Forte explains, for Machiavelli religion is only interesting for its civilising capacity: "It became the ethos of a body politic, an educational authority (Machiavelli sometimes interchanges education and religion) which imprints a "form" upon the social "material", $[\ldots]$. This allows for "carrying out the transition from a purely military State towards the civiltà" (Discourses, I, I). For this reason, the role of religion takes on greater importance during great historical moments: "Machiavelli affirms: 'and in truth they have had to resort to a god all those who gave extraordinary laws to a people, because by any other manner they would not be accepted [...] (Discourses, I, X). Religion serves $[\ldots]$ to legitimise in general all those actions which $[\ldots]$ require extraordinary legitimacy" (Forte 2011, CVII).

\section{Dialectics of constitutional legitimacy}

Collectively, the citizen is recognised in his legal definition as long as he historically expresses unconditional ideals (of justice, equality, etc.) through sincere evidence. The State of divine right is natural; but the modern State is a fabrication and the link between the historical form and the absolute supplied by religion is only instrumental to the preservation of an artifice, meaning that that artifice is not further legitimised. It was precisely in polemics with the claim of the French revolutionaries to be founding a rational State that the ultramontane legitimist Joseph de Maistre argued for the idea of freedom as voluntary submission to one's superior, stemming

${ }^{2}$ Cf. Villacañas and Oncinas in Rodríguez and Villacañas (1999). 
from an awareness of human limitations and the consequent demonstration of the illegitimacy of all secular power not established by divine right. The divine foundation is a miracle impossible to apprehend by reason, demonstrating the action of God upon History. Given this, establishing a rational State feels like a banality, since science, which consists of indefinite chains of causal relations, cannot provide a scientific principle to politics, which is necessarily located beyond science. Hence de Maistre concludes that all States have an irrational or mysterious religious foundation, and so the revolutionary conflict is not between the State of divine right and a hypothetical rational State, but between legitimate and illegitimate principles of coercive power. The basis of the State is its legitimacy, and religion is an instrument for such an end:

"In the political order, $[\ldots]$ it is necessary to rely on an opinion or a belief broad and deep: for if the opinion does not hold the majority of minds and is not deeply rooted, it will provide only a narrow and transient base. Now, if you seek the great and solid bases of all possible institutions [...], you will always find religion and patriotism. And if you reflect still further, you will find that these two things are identical, for there is no true patriotism without religion" (De Maistre [1793 - 1798] 1884).

Only the State based on mystery can resist rational critique. This also applies to the French revolution, for which the idea of principle acquires a central dimension, where freedom coincides with a historical beginning. If a revolution is illegitimately violent and contrary to "natural" principle, it could be affirmed that the natural legitimation of revolutionary power is also the ideal at the time of its foundation as a civilising principle, a miraculous fact, the work of God. De Maistre completes the Machiavellian reflection that the legitimacy of the methods is conferred by the violence of the State and that of the objectives by theology. ${ }^{3}$

\footnotetext{
${ }^{3}$ It is worth noting that a similar point was made by Walter Benjamin in his Critique of Violence, seeking the possibility of breaking the cycle of mere succession of absolute principles of the State as a condition of the preservation of the State as such throughout its transformations. The state, "fears [...] violence simply for its lawmaking character, being obliged to acknowledge it as lawmaking whenever external powers force it to concede them the right" (Benjamin 1996, 241). These forces are war and strikes. Benjamin equated the Law-making violence of the political strike to "violence as a means to the ends of the State". If one creates Law, the other preserves it, but both tend to the preservation of the State. But from that Benjamin deduced something further: the political strike is the founder of (a new) Law and tends towards the reinforcement of the State since it seeks to bestow upon it its legitimate purpose. In contrast, the proletarian strike looks to overcome social relations based on power and coercion. "For it takes place $[\ldots]$ in the determination to resume only a [...] work, no longer enforced by the state" (Benjamin 1996, 246).
} 


\section{Patriotism and despotism}

Patriotism operates equally in the sphere of legitimation of whichever historical State form, via the sentimental connection with the unconditional. Religion acts in the sphere of the passive acceptance of the laws; while love of the country justifies voluntary public service, even against individual interests. Maurizio Viroli $(2004,6)$ has defined Florentine republican patriotism as "a passion that grows between equal citizens [...]. Given that it is a passion it translates into action, and more precisely, into acts of service to the common good (officium) and acts of care (cultus)" ${ }^{4}$ It is characterised by love of shared assets and freedom, which is different to the "natural" nationalist love for the homeland, also possible under despotism. Republican patriotism is civilised and unnecessary in States governed by despots. It is fomented by good education and good laws and is not only active with respect to the preservation of the State, but also in its regeneration and transformation.

Viroli (2004, 8 and ff.) cites a long classical tradition of patriotic criticism of despotism coming to define it as life submitted to the arbitrariness of another will. Undoubtedly, the sensation of injustice has historically kindled revolutionary republican practice, though sometimes, - like in Pettit $(2002,50)$, for example - arbitrariness is matched with pointlessness, rendering despotism incomprehensible. However, from an examination of the mechanisms of ideological identification between the subjects and the State, despotism could also be understood in terms of the effects of delegitimisation inherent in the historical condition of political systems and their empirical succession: as preservation of the State in its purely coercive form in the face of the rupture of consensus on the sovereign. The fact that the sovereign may appear as the holder of an illegitimate power demonstrates a rupturing of the link between the State as violence and its transcendent necessity in the view of the citizens, which turns submission into terror and pushes them to desert their duties and resist power. For Hegel (2012), for example, the barbarian knowledge that only one is free makes that one a despot with arbitrary will, even if he is good-natured. But even this despot is submitted to fixed inherited customs and traditions just like his subjects. The only one who is free is the absolute, constituent, founding whole, who imposes himself in a natural and direct way, provoking terror in the individual of his alienation in a fossilised social role.

\section{The constitutional constitution of the subject}

Legitimacy originates in consensus and the assent of those recognised as free subjects. Hence the State, as guarantor of non-domination, not only has the function of

${ }^{4}$ Viroli mentions among its antecedents Livy's Roman idea of patriotism as read by the scholastic Bartholomew of Lucca, who combines it with Christian caritas. 
expanding the subjects' field of freedom to its possible extent. It also establishes a constitutive Right to freedom for those who obtain the condition of interlocutor in the public processes of rationalisation. The social sphere does not emerge from a mere aggregation of wills. It is an artifice originating in the subjects' political praxis, although it later acquires an autonomous status with respect to these subjects and submits them to their constitutional definition. If individual choices based in the autonomy of the self are not subsequently rationalizable, the State is constituted as an autonomous space for the retroactive rationalisation and positive definition of each individual claim or ideal of life. ${ }^{5}$ From this perspective, regarding the above Viroli's distinction between republican patriotism and nationalism, what is relevant is not the difference between the constitution of the subject as a result of rational dialogic praxis or of historical conditioning, but its relationship with its public definition: the historical dialectic between identification and deidentification which makes this definition seem, or not seem, legitimate.

But can what precedes the act of individuation via its public definition be called a "subject"? Republican theory postulates the existence of an autonomous subject whose nature consists in wanting: in giving himself his own purpose independently of the given thing with which he is historically related, this autonomy being the generative element of the political community. Though the subject does not precede society and strictly exists only in historical form, where the effective transition from political freedom to total freedom cannot take place. If historical representation is total, that is, the full identification between subject, State, and the universal, the individual represented would be eliminated and so too would history. There is no politics that corresponds to the full self-fulfilment of society independent of historical oppressors and liberators.

Legislative practice is ruling as historical rational action of subjects who do not remain simply as individuals, but who become universalised (in the sense of a pragmatic universality of political mediations) in deliberation over a plurality of demands. To use the expression of Judith Butler (2002, 11 - 43), the legislator "translates" the particular subjects to each other; or it generates what Ernesto Laclau (2002) denominate "equivalences", which in both cases means to implement procedures of universalisation of each individual on the basis of their indefinite substitutability. The paradox is that what eludes symbolisation is precisely the most subjective aspect of the individual. Laclau $(2002,70)$ and Slavoj Žižek $(2002,235)$ call this point of failure "suture". It does not express normative content, but the content excluded from discourse: the disturbing short-circuit between different levels that must be reconnected.

\footnotetext{
${ }^{5}$ Rationalisation takes place through an intersubjective communicative historical practice. It does not appear tied to a kingdom of ends, where each individual acts as if their resolve were to be constituted in universal law. It consists rather in a concrete practice of the manufacturing of consensus.
} 


\section{Historicism and rationality}

Gramsci $(1975,764)$ characterises hegemony precisely as dependent on a rhetorical core of persuasion acting as the mortar of such reconnection, capable of obtaining the consensus of the hegemonised or subalterns. As Laclau (2002, 62 and ff.) advises, this process of contingent universalisation is a rhetorical practice and the articulation between subjects and the social roles that define them depends on a metaphor, a figure of speech that only halfway mediates the universality of the political praxis. This is why, perhaps, Gramsci considered the Machiavellian Prince "as a historical exemplification of the myth" later updated by Croce. "Passion is reconstructed in 'affection', fever, fanaticism of action"; although - and on this point Gramsci goes a step further - not only was the myth necessary, but also the "criticism of the myth" and its consequent practice of desertion from prejudices and stunted traditions subjecting subjects to a straitjacket (Gramsci 1975, 1557). Croce, upon presupposing the idea, also needed to presuppose a motivating "passion" to settle the dislocation between world and consciousness in a free act originating in thought. What he called "ethical-political history", or ethical-political realisation of the spirit, was based on a secular "religion" of liberty indefinitely extended, in the sense of "conception of reality that has been transmuted into faith, converted into the basis of action and light of moral life" (Croce, 1924, 341). Croce intended to save freedom by introducing a sentimental element into the very core of praxis, which to Gramsci seemed an unjustified extrapolation from an aesthetic category. Gramsci $(1975,452)$ concedes that "History-politics cannot be made without passion". But he also insists that the philosophy of praxis implies the "critique of the political moment as a moment of passion", which for Croce is essential for explaining the reality of the spirit (Gramsci 1975, 1223). ${ }^{6}$ This highlights the two aspects of hegemony: both communicative rationalisation and "revolutionary" practice of demystification that historicises all intuitive or passionate evidence of the unity between the subject and its representation. ${ }^{7}$

\section{Universalities in conflict}

The philosophy of professional philosophers and that of philosophers in terms of thinking humans corresponds, on the one hand, to a gradation from common sense, contradictory and dialectal, to rational, universalizable discourse, and, on the other

\footnotetext{
${ }^{6}$ Similarly, Gramsci explains "vulgar materialism" as a passion in the face of the "appearance" to consciousness of an individual who is pure, unmediated universality: "the real will disguises itself as an act of faith in a certain rationality of history, in an empirical and primitive form of impassioned finalism" (Gramsci 1975, 1064).

${ }^{7}$ See for example; Gramsci $(1975,426)$.
} 
hand, to its hegemonic or subaltern character: its power depends on the universality derived from its systematic exposition or its fragmentary character, which formally replicates the division between Prince and citizen. The leader defines the subaltern through his legislative activity, and the subaltern recognises themselves (providing assent) through this, and as a function of this they recognise the Prince. But both share the same human character and from this potential identity it is possible to reverse the subaltern situation in the historical future.

Hegemony appears like a subjective relationship of domination and here in particular the Gramscian Hegel comes into play (Gramsci 1975, 1326). On the one side, for Hegel all authority is recognised authority. As Terry Pinkard (2018, xxviii) writes, "If self-consciousness requires recognition by another self-conscious person, then the other person has to have the authority to bestow that recognition". On the other side, from the rationalisation of the master-servant relationship it comes to pass that none of these poles can exhaust human existence. By theorising the right of the servant to power, to his potential lordship, Hegel theorises bourgeois society, where - as Gramsci $(1975,1063)$ says - "all men are philosophers". He condemns the Ancien Régime and its hierarchies to blows and establishes a programme of emancipation by equality through legal recognition, which implies rationalising and objectifying the direction of social production according to a principle of empowerment from the determinability in which consciousness is placed.

Thus, Hegel is, for Gramsci (1975, 1626-1627), "the theoretical precursor of the liberal revolutions of the $1800 \mathrm{~s}$ " because he discovers in the servant, through his condition of worker for somebody else, the human condition and its right. A human condition that, however, he tends to reduce to the condition of the master. Gramsci takes Hegel to his limit, historicising the game of control inscribed in the dialectic of master and servant. He realises that the cunning of reason in liberal democracy means that reason will always be in agreement with power. The dialectic of master and servant can also involve an exercise in universalisation of the experience and particular historical determination of the bourgeoisie, through a "historicist sophism of the underdeveloped classes" (Gramsci 1975, 973), which denies them recognition as self-determined and justifies public education and coercion as essential elements of the State. ${ }^{8}$ In theory, the process should lead to the abolition of the servant, that is, of the "underdeveloped pole" (Gramsci 1975, 1368). In practice, every relation of hegemony is necessarily a pedagogic relationship" (Gramsci 1975, 1331). Gramsci $(1975,973)$ agrees with the sarcasm of Bertrando Spaventa about education in the colonies: "some would like to maintain the underdeveloped classes permanently in the cradle".

${ }^{8}$ Cf. also Gramsci 1975, 1061, 1368, 1370. 


\section{Conclusion}

The dialectics of freedom and oppression from the perspective of the legitimacy of political rule, is sustained by the inconsistency between the subject and his recognised historical-legal form. When legislative practice makes the subject a mere reflection of the constitution of the State, the general will exists at the expense of individual will. If the constitution defined the subjects perfectly, we would have as a result a perfect ahistorical State. It would be more like a religious community.

When society appears to itself and not as the subject, the struggle for the recognition of his rights is begun. The subject questions that which is presented as unquestionable, and the whole is transformed with the former's emergence. Though the resulting subjective identification with the subject's public definition is expressed in a pre-existing, historical language. The available categories of identification restrict in advance the way in which disharmony and the rearticulating of the possible by the oppressed consciousness take place in the face of forced identification. Then, the problem of the a priori impossibility of enunciating what is to be done (its purely retrospective rationality) is resolved through the investment in some kind of norms that may give rise to a decision, which supposes a rhetorical substitution of the impossible object of the ethical investment. If the radical ethical investment is a "pure decision" that, at the same time, must be collectively accepted, what is significant is not the rationality of the ethical act, but the ethical act insofar as it acquires the capacity of persuasion over the universality of its claims and makes itself rational, meaning, real. Thus, if the decision is contingent, its rational foundation is not relevant. Altogether, the self-determined political act occurs within a social context that makes it possible and redefines the possible; it opposes the social context from the point of view of its inherent impossibility and achieves the impossible. Through its praxis, retroactively creates the subject's conditions of possibility. It does not simply define or redefine his constitutional definition, but transforms the public dimension that sustains him in a mutual, bidirectional recognition.

As the republican State is the arena of struggles for the absolute meaning of the historical mode of objectification of the free subject, it is always tied to coercion. Together with the apparatuses of public opinion formation and identification, it also develops coercive institutions which are both the core of the State and strictly anomalies, affronts to the subject as self-determined and to the State as rational. The subject does not oppose these only with the methods provided by the State itself. Machiavelli believed that the subject has no right to oppose the Prince if it is not with the legal means that the Prince allows. However, history shows that the subject also de facto opposes the Prince through delinquency, corruption, madness, or - above all - 
the struggle which culminates in the foundation of a new State that is the new, real truth of freedom.

\section{Bibliography}

BENJAMIN, W. (1996): Critique of Violence. In: Jennigs. M. W. (ed.): Walter Benjamin. Selected Writings, Vol. 1 (1913 - 1926). Cambridge: Belknap Press, 236 - 252.

BUTLER, J. LACLAU, E., ŽIŽEK, S. (2002): Contingency, Hegemony, Universality: Contemporary Dialogues on the Left. London: Verso.

CROCE, B. (1924): Storia economico-politica e storia etico-politica. La Critica, 22, 334 - 341.

DE MAISTRE, J. ([1793 - 1798] 1884): Study on Sovereignty. [online] http://maistre.uni.cx/sovereignty.html (Accessed on 01-06-2020).

FORTE MONGE, J. M. (2011): Introduction to Maquiavelo. Madrid: Gredos, 2011, I - CXXIX.

GRAMSCI, A. (1975): Quaderni del carcere. Turin: Einaudi.

HABERMAS, J. (1994): Human Rights and Popular Sovereignty: The Liberal and Republican Versions. Ratio Juris, 7 (1), 1 - 13.

HEGEL, G. W. F. (2018): The Phenomenology of the Spirit. Cambridge: Cambridge University Press.

HEGEL, G. W. F. (2012): Lectures on The Philosophy of History. Cambridge: Cambridge University Press.

MACHIAVELLI, N. (1938): Opere. Milan - Rome: Rizzoli \& C., Editori, 1938.

MACHIAVELLI, N. (1996): Discourses on Livy. Chicago: The University of Chicago Press.

ONCINAS, F. (1999): Maquiavelismo y antimaquiavelismo. In: Rodríguez, R. - Villacañas, J. L. (eds.): La herencia de Maquiavelo, modernidad y voluntad de poder. Mexico City: Fondo de Cultura Económica, 77 - 102.

PETTIT, Ph. (2002): Republicanism. A Theory of Freedom and Self Government. Oxford: Oxford University Press.

SANDEL, M. (2005): Public Philosophy. Essays on Morality in Politics. Cambridge. Harvard University Press.

VILLACAÑAS. J. L. (1999): Principe nuovo y vivere politico. In: Rodríguez, R. - Villacañas, J. L. (eds.): La herencia de Maquiavelo, modernidad y voluntad de poder. Mexico City: Fondo de Cultura Económica, 15 - 38

VIROLI, M. (2004): El sentido olvidado del patriotismo republicano. Isegoría, 24, 5 - 14.

This work has been funded by the research project Biografia colectiva y análisis prosopográfico más allá del Parlamento from the Ministerio de Ciencia, Innovación y Universidades, Spain (PGC2018-095712-B-100) and by the Basque Government through the research Group Biography \& Parliament (IT-1263-19).

Juan José Gómez Gutiérrez

Faculty of Philosophy

University of Seville

Camilo José Cela, $\mathrm{S} / \mathrm{N}$

41018 Seville

Spain

e-mail: jgomez32@us.es

ORCID ID: https://orcid.org/0000-0003-3951-6912 